University of Nebraska - Lincoln

DigitalCommons@University of Nebraska - Lincoln

$4-15-2019$

\title{
Growth, Condition, and Trophic Relations of Stocked Trout in Southern Appalachian Mountain Streams
}

\author{
Jesse R. Fischer \\ North Carolina State University \\ Thomas J. Kwak \\ North Carolina State University, tkwak@ncsu.edu \\ H. Jared Flowers \\ North Carolina State University \\ W. Gregory Cope \\ North Carolina State University \\ Jacob M. Rash \\ North Carolina Wildlife Resources Commission
}

See next page for additional authors

Follow this and additional works at: https://digitalcommons.unl.edu/usgsstaffpub

Part of the Geology Commons, Oceanography and Atmospheric Sciences and Meteorology Commons, Other Earth Sciences Commons, and the Other Environmental Sciences Commons

Fischer, Jesse R.; Kwak, Thomas J.; Flowers, H. Jared; Cope, W. Gregory; Rash, Jacob M.; and Besler, Douglas A., "Growth, Condition, and Trophic Relations of Stocked Trout in Southern Appalachian Mountain Streams" (2019). USGS Staff -- Published Research. 1104.

https://digitalcommons.unl.edu/usgsstaffpub/1104

This Article is brought to you for free and open access by the US Geological Survey at DigitalCommons@University of Nebraska - Lincoln. It has been accepted for inclusion in USGS Staff -- Published Research by an authorized administrator of DigitalCommons@University of Nebraska - Lincoln. 


\section{Authors}

Jesse R. Fischer, Thomas J. Kwak, H. Jared Flowers, W. Gregory Cope, Jacob M. Rash, and Douglas A. Besler 


\title{
Growth, Condition, and Trophic Relations of Stocked Trout in Southern Appalachian Mountain Streams
}

\author{
Jesse R. Fischer \\ North Carolina Cooperative Fish and Wildlife Research Unit, Department of Applied Ecology, \\ North Carolina State University, Raleigh, North Carolina 27695, USA
}

\section{Thomas J. Kwak*}

U.S. Geological Survey, North Carolina Cooperative Fish and Wildife Research Unit, Department of Applied Ecology, North Carolina State University, Raleigh, North Carolina 27695, USA

\author{
H. Jared Flowers ${ }^{1}$ \\ North Carolina Cooperative Fish and Wildlife Research Unit, Department of Applied Ecology, \\ North Carolina State University, Raleigh, North Carolina 27695, USA
}

\author{
W. Gregory Cope \\ Department of Applied Ecology, North Carolina State University, Raleigh, North Carolina 27695, USA
}

\author{
Jacob M. Rash and Douglas A. Besler \\ North Carolina Wildife Resources Commission, Division of Inland Fisheries, 645 Fish Hatchery Road, Marion, \\ North Carolina 28752, USA
}

\begin{abstract}
Stream trout fisheries are among the most popular and valuable in the United States, but many are dependent on hatcheries to sustain fishing and harvest. Thus, understanding the ecology of hatchery-reared trout stocked in natural environments is fundamental to management. We evaluated the growth, condition, and trophic relations of Brook Trout Salvelinus fontinalis, Brown Trout Salmo trutta, and Rainbow Trout Oncorhynchus mykiss that were stocked in southern Appalachian Mountain streams in western North Carolina. Stocked and wild (naturalized) trout were sampled over time (monthly; September 2012-June 2013) to compare condition and diet composition and to evaluate temporal dynamics of trophic position with stable isotope analysis. Relative weights $\left(W_{r}\right)$ of stocked trout were inversely associated with their stream residence time but were consistently higher than those of wild trout. Weight loss of harvested stocked trout was similar among species and sizes, but fish stocked earlier lost more weight. Overall, $40 \%$ of 141 stomachs from stocked trout were empty compared to $15 \%$ of wild trout stomachs $(N=26)$. We identified a much higher rate of piscivory in wild trout (18 times that of stocked trout), and wild trout were 4.3 times more likely to consume gastropods relative to stocked trout. Hatchery-reared trout were isotopically similar to co-occurring wild fish for both $\delta^{13} \mathrm{C}$ and $\delta^{15} \mathrm{~N}$ values but were less variable than wild trout. Differences in sulfur isotope ratios $\left(\delta^{34} S\right)$ between wild and hatchery-reared trout indicated that the diets of wild fish were enriched in $\delta^{34} \mathrm{~S}$ relative to the diets of hatchery-reared fish. Although hatcheryreared trout consumed prey items similar to those of wild fish, differences in consumption or behavior (e.g., reduced feeding) may have resulted in lower condition and negative growth. These findings provide critical insight on the trophic dynamics of stocked trout and may assist in developing and enhancing stream trout fisheries.
\end{abstract}

*Corresponding author: tkwak@ncsu.edu

${ }^{1}$ Present address: Georgia Department of Natural Resources, Coastal Resources Division, Brunswick, Georgia 31525, USA.

Received February 12, 2019; accepted April 15, 2019 
Lotic trout (family Salmonidae) fisheries are among the most popular and valuable in the United States (USFWS and USCB 2011) but are also among the most dependent on hatcheries as a result of numerous factors, including loss of habitat from anthropogenic activities, overexploitation, and the popularity of and public demand for angling opportunities. Understanding the ecology and life history of hatchery-reared trout in natural environments was fundamental to assessing the efficacy of captive breeding and stocking programs (e.g., Needham and Slater 1944, 1945; Miller 1952, 1953) and is increasingly necessary to manage fisheries as the reliance on stocking activities increases (Heidinger 1999; Halverson 2008; Trushenski et al. 2010). High mortality and low returns to the creel for stocked individuals resulted in early research on stocking larger fish as a management practice, and stockings of catchable-sized trout have been well documented to increase creel returns relative to smaller fish (Needham 1959; Cresswell 1981; Wiley et al. 1993a; Walters et al. 1997). Additionally, despite greater production cost per fish, the stocking of larger fish is often more economical than stocking sub-catchable trout (Wiley et al. 1993a; Walters et al. 1997). However, rearing fish to large sizes may produce fish that are maladapted to natural environments without additional conditioning (e.g., feed training, habitat enhancement, and density reduction; Wiley et al. 1993b). As such, assessing the poststocking dynamics (e.g., survival, behavior, and creel return) of hatcheryreared fishes is essential for efficient management of trout fisheries.

Quantifying the mechanisms responsible for success of hatchery-reared trout after stocking, such as increased recreational catch or survival, is complex because several critical components of the environment of stocked fish (e.g., density, cover, and food) are abruptly changed during the transition from the hatchery to the wild. One of the most ecologically significant changes from hatchery to stocking is the termination of regular feeding and the abrupt introduction to wild food sources. However, most research on the trophic relations of hatchery-reared trout has focused on competition between domesticated and wild stocks (reviewed by Einum and Fleming 2001; Weber and Fausch 2003) or the potential ecological effects of hatchery-reared trout on other aquatic organisms (e.g., nonsalmonid fish assemblages; Weaver and Kwak 2013; Turek et al. 2014). In numerous cases, however, the stocking of hatchery-reared trout occurs in waters that cannot support self-sustaining trout populations or where production is severely limited, such as coolwater rivers. Additionally, stocking of large apex predators at high densities may lead to negative ecological effects (e.g., higher energetic demand and less gape limitation), but stocking of catchable-sized fish for recreational objectives implies limited duration and, thus, minimal negative trophic interactions. Furthermore, studies of hatchery-reared trout stocked at catchable sizes have demonstrated detrimental behavior, feeding, and growth that result in poor survival (Bachman 1984; Weber and Fausch 2003). Therefore, understanding the trophic relations of hatchery-reared individuals after stocking is especially important for trout fisheries that attempt to limit or delay harvest and provide catch-and-release fisheries prior to harvest.

Management of fisheries that rely on supplemental stocking is often conducted without information on the diet and feeding habits of hatchery-reared fish in their new environment. However, information on trophic relationships is fundamental to understanding the patterns and dynamics of complex ecosystem processes (Polis and Winemiller 1996). Traditional analyses of trophic relationships were limited to studies of diet composition constructed from fish stomach contents (e.g., Teixeira and Cortes 2006). Diet composition is a useful parameter because it provides direct relationships between consumers and prey. However, prey availability may change seasonally in temperate aquatic systems, such as in mountain trout streams. The use of stable isotopic composition of consumers relative to prey can provide an integrated assessment of trophic relationships for the entire food web (Peterson and Fry 1987). Generally, carbon $\left(\delta^{13} \mathrm{C}\right)$ isotopic composition may reveal changes in food sources, nitrogen $\left(\delta^{15} \mathrm{~N}\right)$ values estimate the trophic level of consumers, sulfur $\left(\delta^{34} \mathrm{~S}\right)$ values differentiate between marine (e.g., fish meal in commercial feed) and freshwater sources, and the variation in isotopic signature may indicate diet breadth (Fry 1991). As such, stable isotope analysis (SIA) may provide insight into the trophic dynamics of hatchery-reared trout and may provide information directly comparable with that from conspecific wild individuals.

Our aim was to describe the trophic relations of three economically important coldwater sport fishes (Brook Trout Salvelinus fontinalis, Brown Trout Salmo trutta, and Rainbow Trout Oncorhynchus mykiss) that are commonly propagated and stocked throughout lotic systems in North America. Specifically, our objectives, focusing on southern Appalachian Mountain stream trout fisheries, were to (1) quantify changes in the densities of trout that were repeatedly stocked into delayed-harvest reaches (i.e., catch and release before allowed harvest), (2) characterize the temporal dynamics of growth and condition and assess the effect of residence time on harvested trout from repeated stockings, (3) quantify and compare the diet composition of coexisting wild and stocked trout, and (4) describe the trophic position and temporal dynamics of stable isotopic composition for hatchery- and wild-origin trout. The intended application of this research is to enhance the understanding of stocked trout ecology to guide management toward efficient and successful fisheries. 


\section{STUDY SITES}

We studied hatchery-reared and wild (naturalized, unstocked populations) Brook Trout, Brown Trout, and Rainbow Trout in southern Appalachian Mountain streams located in western North Carolina. The genetic origins of trout reared in state hatcheries and stocked in mountain streams were not pure wild-stock strains and included genetics of multiple strains bred in hatcheries over generations. Specifically, we intensively investigated the body condition, diet, and trophic position of trout from three streams (Cane Creek [CC]: $36.0147^{\circ} \mathrm{N},-82.1585^{\circ} \mathrm{W}$; North Toe River [NTR]: $35.9125^{\circ} \mathrm{N},-82.0655^{\circ} \mathrm{W}$; East Prong Roaring River [EPRR]: $\left.36.3972^{\circ} \mathrm{N},-81.0637^{\circ} \mathrm{W}\right)$. Study reaches on all three rivers were managed by the North Carolina Wildlife Resources Commission (NCWRC) as Delayed Harvest Trout Waters (hereafter, "delayed-harvest reaches"). Within each delayed-harvest reach, Brook Trout, Brown Trout, and Rainbow Trout were stocked monthly during the fall (October and November) and spring (March, April, and May) to provide increased catch-and-release angling opportunities prior to the opening of harvest in early summer. Two size categories of fish were stocked (determined by the NCWRC): "catchable" (mean TL $=268 \mathrm{~mm}, \mathrm{SD}=29.2$ ) and "large" (mean TL $=391 \mathrm{~mm}, \mathrm{SD}=44.2$ ). The categories were not precisely based on size but were primarily based on differing hatchery protocols and stocking procedures. The delayed-harvest approach seeks to maximize the efficiency of hatchery-reared fish by allowing individuals to be caught multiple times prior to harvest. The delayed-harvest reaches of each river were located in areas that offered public access for anglers. The study areas for CC and NTR were located within the towns of Bakersville and Spruce Pine, respectively, while the study area for EPRR was located in Stone Mountain State Park. To supplement information on the body condition of wild trout sampled from delayed-harvest reaches, data from standardized surveys of western North Carolina mountain trout streams that were not stocked were also included. Specifically, weight (g) and TL $(\mathrm{mm})$ of wild trout from 20 additional southern Appalachian Mountain rivers sampled between 2010 and 2015 (five rivers per year) were selected for comparison to trout sampled or harvested from delayed-harvest reaches of CC, NTR, and EPRR.

\section{METHODS}

Temporal characteristics of hatchery-reared trout density, condition, and growth.-Changes in density, body weight, and condition of hatchery-reared fish within delayed-harvest reaches were assessed through repeated surveys conducted on CC and EPRR (2012-2013). Prior to each stocking, individual fish were marked using a combination of fin clips and coded wire tags at the hatchery. Pulsed-DC backpack electrofishing (Smith-Root Models
LR-24 and LR-20B; Smith-Root, Vancouver, Washington) was conducted at two reaches $(100 \mathrm{~m}$ each) on each river by using a three-pass removal method with equal effort among passes for estimation of trout density. Trout density was estimated according to species by using a maximum-likelihood method for three-pass removals (Seber 1982; Hayes et al. 2007) with the FSA package (Ogle 2018) in R version 3.5.1 (R Core Team 2018). Sampling occurred every 2-4 weeks from September 2012 (prior to the first stocking) until May 2013, which preceded the harvest season and spanned beyond the final stocking. All trout were weighed $(\mathrm{g})$, measured (TL, $\mathrm{mm}$ ), and checked for marks and tags to determine stocking date and origin. Relative weight ( $W_{r}$; Neumann et al. 2012) is a standard index of fish body condition that allows for comparison among individuals of varying size, as well as populations and species. Based on standard weight parameters compiled by Neumann et al. (2012), we calculated $W_{r}$ for all hatchery-reared trout sampled to evaluate temporal (i.e., residence time) and density trends in body condition.

Changes in body weight and $W_{r}$ of hatchery-reared fish were also measured from individually tagged, stocked, and harvested trout in NTR (2012-2013) and EPRR (20132014). Before each of the five stocking occasions, 23-mm PIT tags were injected into the body cavities of approximately 200 individuals/species, resulting in 600 tagged trout per stocking event and 3,000 total tagged trout per river (Flowers et al. 2019). Trout were tagged several days before scheduled stockings and were held to monitor posttagging condition; laboratory studies revealed that any tagging effects are short term (Bateman and Gresswell 2006). Weight ( $\mathrm{g}$ ) and length (TL, mm) of each tagged fish were recorded at the hatchery and at angler check stations operated during the morning of the harvest season's opening day (June 8, 2013, NTR: 112 recaptures; June 7, 2014, EPRR: 58 recaptures). Differences in body weight (i.e., absolute growth) measured from the time of stocking to harvest were assessed as proportional changes for individually tagged fish. Changes in condition between stocking and harvest were expressed as the change in $W_{r}$ over time.

Diet and stable isotope analysis. - An evaluation of wild and hatchery-reared trout diet composition based on stomach content analysis and SIA were conducted for delayedharvest reaches of CC and EPRR to assess potential differences in trophic ecology and explore the temporally dynamic mechanisms that were potentially responsible. Samples for SIA were obtained from repeated backpack electrofishing surveys conducted from September 2012 to May 2013 (see previous methods). Up to three individuals per trout species and origin were collected at each sampling occasion (167 total trout) and were stored whole on ice in the field. Fish were then frozen and retained for determination of diet and excision of white-muscle tissue samples in the laboratory. Stomachs of thawed trout were 
dissected, and their contents were removed and identified to the lowest possible taxonomic level to document presence of prey categories for comparisons between origins and among species. Frequency of occurrence was estimated for all stomach content items identified into classes, including fish, insect, crustacean, gastropod, sand, pebble, wood, plant material, artificial material, and empty (Bowen 1996).

Additional potential basal food web sources and other consumers were collected from each stream by using pulsed-DC backpack electrofishing (e.g., cyprinids and centrarchids), D-frame nets and kick nets (e.g., benthic and drifting macroinvertebrates and other organic matter), and grab samples (e.g., detritus and epiphytic algae) for SIA on a single occasion during summer after the trout harvest season's opening day $(N=182$ samples; see previous methods). All samples were immediately placed on ice after collection and were frozen until later identification and processing in the laboratory. Three individuals of each trout species and commercial feed samples (Skretting USA Salmon extruded sinking pellets) were also obtained from the Armstrong State Fish Hatchery (Marion, North Carolina) for estimates of initial trophic position (as nitrogen isotopic composition) relative to trout stocked previously and natural prey sources.

All samples collected for SIA were identified and processed in the laboratory after thawing. Individual white muscle tissue samples were excised from all fish. Muscle samples of crayfish and snails were removed from their respective carapaces and shells. Composite tissue samples of more than one individual were formed for invertebrates when low individual weight was insufficient for SIA. Samples of drifting particulate organic matter (POM) were processed after removal of all visible macroinvertebrates under a laboratory magnifying lamp. All SIA organic matter samples were oven-dried at $60^{\circ} \mathrm{C}$ for $24 \mathrm{~h}$ prior to homogenization with a mortar and pestle. Muscle tissue samples removed from crayfish and snails were rinsed with $10 \% \mathrm{HCl}$ to remove any residual calcium carbonate, followed by rinsing with distilled water, and were dried at $60^{\circ} \mathrm{C}$ for an additional $24 \mathrm{~h}$ before homogenization (Kwak and Zedler 1997). Dried and homogenized samples were stored in glass vials until they were weighed, encapsulated in tin, and combusted using a continuous-flow isotope ratio mass spectrometer (IRMS). Carbon and nitrogen stable isotope ratios were obtained from samples using a Carlo Erba NC 2100 elemental analyzer coupled with Thermo Electron Delta V Advantage IRMS configured through a Finnigan CONFLO III for automated continuous-flow analysis. Separately analyzed samples for sulfur stable isotope ratios were conducted using a DELTA plus Advantage IRMS configured through a CONFLO III for automated continuous-flow analysis with a Costech ECS4010 Elemental Analyzer. Analyses of stable isotopes were performed at the Colorado Plateau Stable Isotope Laboratory at Northern Arizona University. Results for each element were expressed as parts per thousand (\%o) differences from the corresponding standard ( $\delta$ ),

$$
\delta X=\left[\left(R_{\text {sample }} / R_{\text {standard }}\right)-1\right] \times 1,000,
$$

where $X$ is ${ }^{13} \mathrm{C},{ }^{15} \mathrm{~N}$, or ${ }^{34} \mathrm{~S}$; and $R$ is the corresponding ratio of ${ }^{13} \mathrm{C} /{ }^{12} \mathrm{C},{ }^{15} \mathrm{~N} /{ }^{14} \mathrm{~N}$, or ${ }^{34} \mathrm{~S} /{ }^{32} \mathrm{~S}$. Standard materials were Vienna Pee Dee belemnite limestone for carbon, atmospheric nitrogen for nitrogen, and Canyon Diablo troilite for sulfur. The $\delta$ values include a measure of both heavy and light isotopes, whereby higher $\delta$ values denote a greater proportion of the heavy isotope.

Statistical analysis. - Nonparametric statistical procedures were used to test associations and compare trophic relations among species and between origins (i.e., hatchery reared and wild), as data did not conform to a normal distribution (Shapiro-Wilk $W$-test: $P<0.05$; Zar 1999). Spearman's rank correlation was used to detect relationships between $W_{r}$ of hatchery-reared trout from repeated sampling (CC and EPRR) and the estimated residence time and density of trout. Relationships between weight at stocking and proportional weight change of harvested trout from NTR and EPRR were also tested using Spearman's rank correlation. The Wilcoxon rank-sum test (unpaired samples) and Wilcoxon's signed rank test (paired samples) were used to compare proportional weight and $W_{r}$ changes between stocking and harvest and between rivers (NTR and EPRR). A Kruskal-Wallis test with post hoc Dunn's test was applied to compare proportional weight and $W_{r}$ changes among species and stocking months for trout harvested from NTR and EPRR. Fish diet and isotopic composition data were pooled among sampling occasions to represent an average or aggregate estimate of the associated parameters. The effect of fish origin (i.e., wild versus hatchery reared) on the diets of trout sampled from CC and EPRR was evaluated using Pearson's chi-square test (Agresti 2007). Spearman's rank correlation was used to assess relationships between $\delta^{13} \mathrm{C}$, $\delta^{15} \mathrm{~N}$, and $\delta^{34} \mathrm{~S}$ values and stream residence time for hatchery-reared trout. A type I error rate $(\alpha)$ of 0.05 was used for all statistical tests, and Bonferroni adjustments were applied to $P$-values for all post hoc comparisons among groups (Dunn 1961).

\section{RESULTS}

\section{Temporal Characteristics of Hatchery-Reared Trout Density, Condition, and Growth}

Mean densities of hatchery-reared trout in both rivers were consistently highest immediately after stocking but 
quickly declined thereafter and prior to subsequent stockings (Figure 1). After the November stocking in both rivers, densities remained low in delayed-harvest reaches until stocking resumed in March. Trout densities throughout winter (December-February) after fall stockings generally declined to prestocking levels observed in September, but densities remained higher for all species in the spring after stocking in March (Figure 1). Relative weights of hatchery-reared trout sampled from repeated backpack electrofishing throughout the closed-harvest season were inversely associated with stream residence time $(N=1,648$, Spearman's $\rho=-0.26, P<0.001)$ and positively associated with density $(N=1,648$, Spearman's $\rho=0.06, P=0.02$; Figure 2).

Overall, weights of harvested trout were lower than those measured prior to stocking for NTR (overall mean weight loss $\pm \mathrm{SE}=-10.1 \pm 0.8 \%$ ) and $\mathrm{EPRR}$ $(-8.9 \pm 0.8 \%)$ and did not differ between rivers ( $W=2,981, P=0.38$ ). Consistent patterns in proportional weight loss from stocking to harvest among species were observed in both rivers. Weight loss was greatest for hatchery-reared Brook Trout in both systems (NTR: $-12.5 \pm 1.6 \%, N=31$; EPRR: $-10.1 \pm 1.3 \%, N=23$ ), followed by Rainbow Trout (NTR: $-10.4 \pm 1.1 \%$, $N=48$; EPRR: $-9.0 \pm 1.0 \%, N=27$ ) and Brown Trout (NTR: $-7.4 \pm 1.5 \%, N=31$; EPRR: $-5.2 \pm 2.2 \%, N=8$ ), but differences among species were not statistically significant for either river (NTR: $\chi_{2, N=112}^{2}=5.48, P=0.06$; EPRR: $\left.\chi_{2, N=58}^{2}=2.53, P=0.28\right)$. Overall, mean $W_{r}$ of harvested trout declined from $102(\mathrm{SE}=1.1)$ at stocking to 87 $(\mathrm{SE}=0.8)$ at harvest in NTR $(W=6,079.5, P<0.001)$ and from $104(\mathrm{SE}=1.8)$ to $94(\mathrm{SE}=1.8)$ in EPRR ( $W=1,646.5, \quad P<0.001)$. Relative weight of hatcheryreared trout at stocking was consistently greater than the $W_{r}$ of wild trout for all species (all $P<0.05$; Table 1), but wild trout $W_{r}$ was generally similar to that of hatchery-reared trout at harvest in both rivers (all $P>0.05$; Table 1).

Change in weight between stocking and harvest was not associated with body weights measured prior to stocking (NTR: Spearman's $\rho=-0.2, P=0.07$; EPRR: Spearman's $\rho=-0.02, P=0.9$; Figure 3 ) but differed among stocking months in each river (NTR: $\chi_{4, N=112}^{2}=24.2$, $P<0.01$; EPRR: $\chi_{3, N=58}^{2}=10.0, P=0.02$; Figure 4). In NTR, percent weight change of harvested trout was lowest for fish stocked in May (Bonferroni-adjusted $P$-values $<0.01$ ), whereas fish stocked during March, April, and May in EPRR did not differ in weight loss (Bonferroniadjusted $P$-values $>0.0125$; Figure 4$)$. The $W_{r}$ of harvested trout differed among stocking months in NTR $\left(\chi_{4, N=112}^{2}=\right.$ 15.4, $P<0.01)$, whereas no significant differences were detected among months in EPRR $\left(\chi_{3, N=58}^{2}=6.0, P=0.11\right.$; Figure 4). Relative weights were similar for trout stocked in March, April, and May prior to harvest in June in both rivers (all $P>0.01$ ), but the $W_{r}$ of trout stocked into NTR in May was greater than that of fish stocked in October and November (Bonferroni-adjusted $P$-values $<0.01$; Figure 4).

\section{Diet and Isotopic Composition of Hatchery-Reared and Wild Trout}

Biplots of mean $\delta^{13} \mathrm{C}, \delta^{15} \mathrm{~N}$, and $\delta^{34} \mathrm{~S}$ isotope ratios (\%o) demonstrated similar patterns of producer-consumer associations between CC and EPRR, with trout among the apex predators in both systems (Figure 5). Particulate organic matter and primary consumers from $\mathrm{CC}$ were enriched in ${ }^{15} \mathrm{~N}$ relative to corresponding organic matter in EPRR. Isotopic differentiation was not observed for trout obtained directly from the Armstrong State Fish Hatchery relative to trout collected from CC and EPRR (Figure 5). However, detailed inspection of species- and origin-specific isotope ratios indicated depletion of ${ }^{13} \mathrm{C}$ and ${ }^{34} \mathrm{~S}$ relative to wild trout (Table 2; Figure 6). Wild trout also exhibited greater variability in mean $\delta^{13} \mathrm{C}$ and $\delta^{15} \mathrm{~N}$ relative to those values for hatchery-reared fish (Table 2; Figure 6). No consistent differences in isotopic composition between $\mathrm{CC}$ and EPRR were observed for any trout species evaluated (Table 2).

Visual examination of the relationships between $\delta^{13} \mathrm{C}$, $\delta^{15} \mathrm{~N}$, and $\delta^{34} \mathrm{~S}$ values and stream residence time for hatchery-reared trout indicated no distinct differences between CC and EPRR and no evidence for temporal trends of stocked fish isotopic composition toward the mean values for wild fish (Figure 7). Associations between $\delta^{13} \mathrm{C}, \delta^{15} \mathrm{~N}$, and $\delta^{34} \mathrm{~S}$ and days since stocking for species and rivers were not significant (all $P>0.05$ ), except for $\delta^{13} \mathrm{C}$ in Rainbow Trout from CC $(N=35$, Spearman's $\rho=-0.47, P=0.005)$. Mean $\delta^{13} \mathrm{C}, \quad \delta^{15} \mathrm{~N}$, and $\delta^{34} \mathrm{~S}$ of wild Brook Trout were consistently greater than values for hatchery fish, whereas mean $\delta^{13} \mathrm{C}$ and $\delta^{15} \mathrm{~N}$ of wild Brown Trout were consistently lower than those of hatchery fish. Hatchery-origin Rainbow Trout were depleted in ${ }^{13} \mathrm{C}$ and ${ }^{34} \mathrm{~S}$ relative to means observed for wild fish (Figure 7).

Diet analysis generally indicated a greater prey frequency in the stomachs of wild trout relative to those of hatchery-reared fish (Table 3). Observed frequencies of prey in hatchery-reared and wild trout differed from those expected for the following prey types: fish $\left(\chi_{1, N=167}^{2}=\right.$ 6.87, $P=0.009)$, crustaceans $\left(\chi_{1, N=167}^{2}=5.44, P=0.02\right)$, and gastropods $\left(\chi_{1, N=167}^{2}=7.42, P=0.006\right)$. Wild trout were 17.7 times more likely than stocked hatchery-reared trout of similar size ranges to consume fish and were 4.3 times more likely to consume gastropods. Crustaceans were never observed in the stomachs of hatchery-reared trout. 

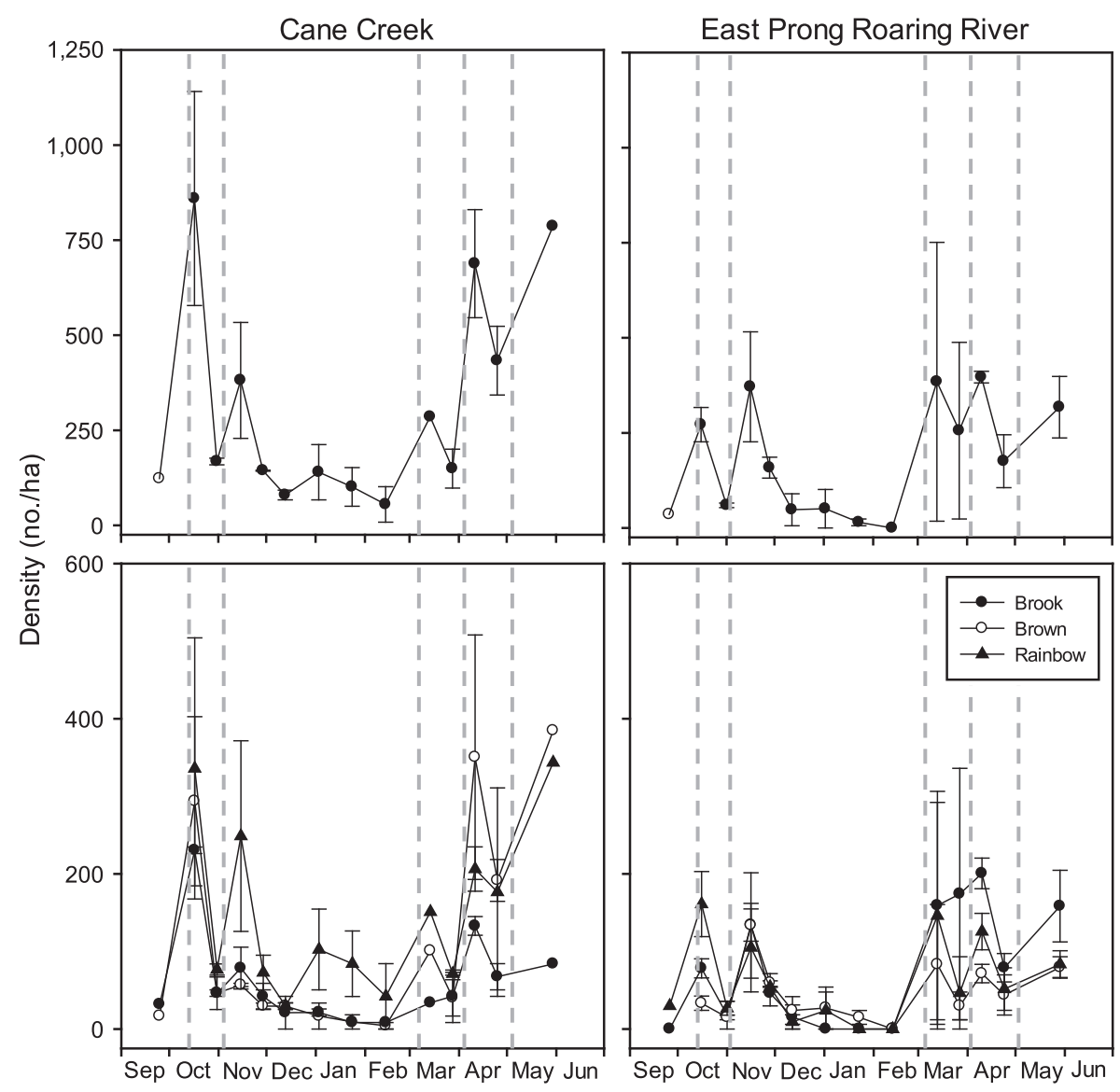

FIGURE 1. Mean $( \pm \mathrm{SE})$ density (fish/ha) of hatchery-reared Brook Trout (Brook), Brown Trout (Brown), and Rainbow Trout (Rainbow) from three-pass removal procedures conducted using pulsed-DC backpack electrofishing at two fixed locations in delayed-harvest reaches of Cane Creek and the East Prong Roaring River, western North Carolina, 2012-2013. Upper panel estimates represent all trout species combined; lower panels are presented according to species. Gray, vertical dashed lines indicate stocking dates.

\section{DISCUSSION}

Overall, we found that densities of hatchery-reared trout were strongly associated with time from stocking, all three trout species consistently lost weight after stocking, and weight steadily decreased with residence time in the three southern Appalachian Mountain streams. However, body condition of trout harvested from reaches that were managed to promote recreational fishing by delaying harvest was similar to that of wild fish populations sampled throughout western North Carolina. Complementary assessments of diet and stable isotope composition suggested reduced diet breadth, lower feeding intensity, and limited incorporation of natural prey resources into body mass for hatchery-reared individuals relative to wild fish, which likely resulted in negative growth and decreased condition with residence time. Specifically, stocked trout were much less likely to consume important prey resources, such as fish, that could be necessary to maintain weight in the stream environment.

\section{Temporal Characteristics of Hatchery-Reared Trout Density}

Delayed-harvest trout regulations were implemented in North Carolina in 1992, and initial assessments in EPRR and the Nantahala River concluded that angler catch rates were 1.7-2.6 times higher than those in traditional putand-take reaches that were also hatchery supported, with immediate harvest allowed (Borawa et al. 1993). However, stocking trout in the fall generally results in lower creel returns and recaptures during the next spring or summer (Cresswell 1981; Walters et al. 1997; Bettinger and Bettoli 2002). Stocking of catchable-sized trout prior to winter in North Carolina Appalachian Mountain streams is done to provide increased recreational fishing opportunities that would otherwise not exist due to low or nonexistent trout production in seasonally suitable waters. The observed temporal patterns of trout density in CC and EPRR suggest that mortality or emigration may differ between stocking in the fall (i.e., October and November) and stocking in the spring (i.e., March, April, and May). 


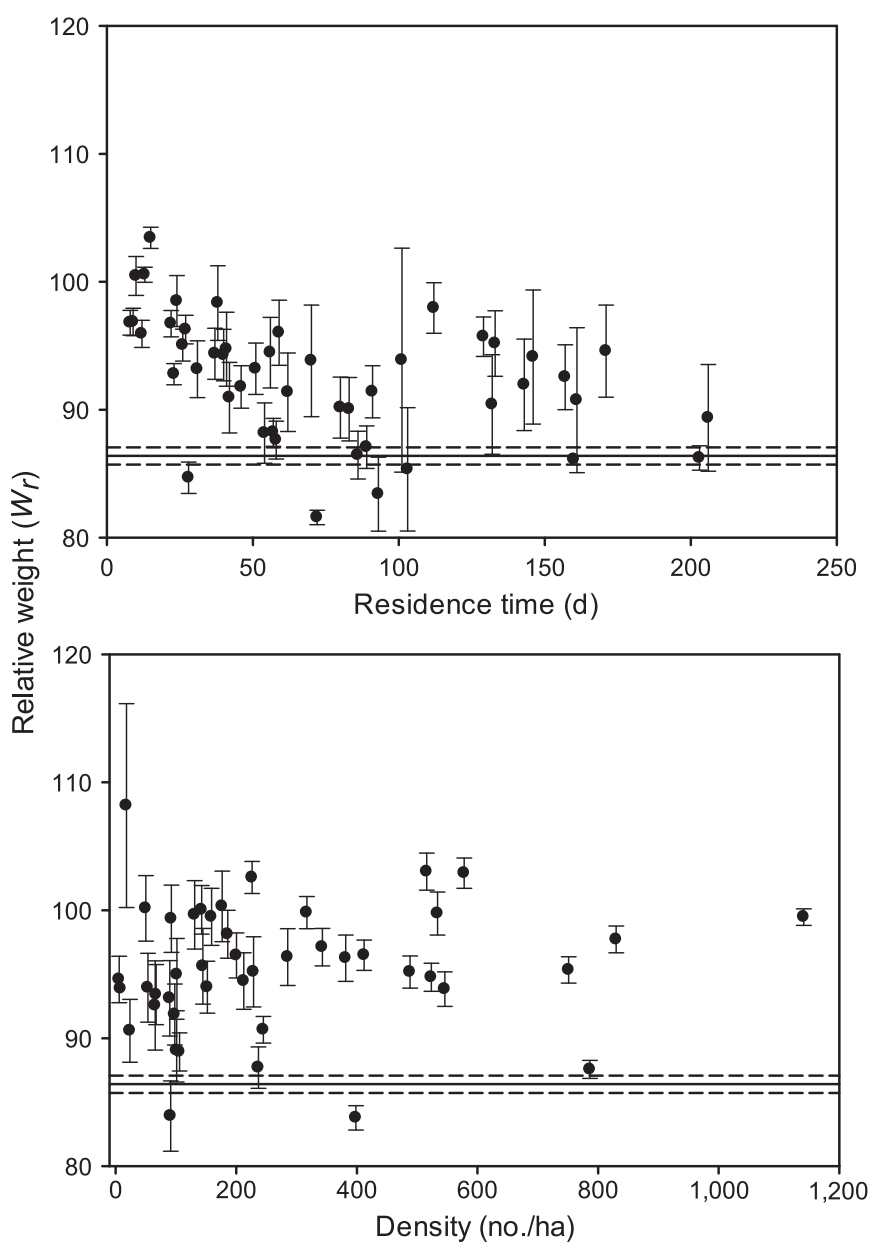

FIGURE 2. Mean $( \pm \mathrm{SE})$ relative weight $\left(W_{r}\right)$ of hatchery-reared trout stocked into delayed-harvest reaches of Cane Creek and the East Prong Roaring River, western North Carolina (2012-2013), versus instream residence time ( $\mathrm{d}$ since stocking; upper plot) and density (fish/ha; lower plot) for Brook Trout, Brown Trout, and Rainbow Trout. Solid reference lines indicate the mean $W_{r}( \pm \mathrm{SE}$, dashed lines $)$ of wild trout $(N=534)$ from 20 North Carolina Appalachian streams.

Specifically, rapid declines in the density of previously stocked trout in CC and EPRR after stocking suggest that overwinter emigration and mortality may limit availability in delayed-harvest reaches (Flowers et al. 2019). Hartman et al. (2012) observed that survival and site fidelity of catchable-sized Rainbow Trout stocked into the Bluestone River, West Virginia, were lowest during winter relative to fall and spring. The rapid movement of trout after stocking has also been previously documented and supports the patterns of density observed. For example, mean 24-h dispersal of radio-tagged Rainbow Trout stocked into the Clinch River, Tennessee, was $1.4 \mathrm{~km}$ (occurred over a 6$\mathrm{km}$ river reach), and fish dispersed over $13 \mathrm{~km}$ within $6 \mathrm{~d}$ of stocking (Bettinger and Bettoli 2002). Therefore, the declines in trout densities to prestocking levels, which we observed in CC and EPRR 2-4 weeks after stocking, may
TABLE 1. Mean relative weight $\left(W_{r}\right.$; with SE) of hatchery-reared trout that were stocked and harvested from delayed-harvest reaches of the North Toe River (NTR) and the East Prong Roaring River (EPRR) in western North Carolina (NC), 2012-2014. Individuals were measured (TL, mm), weighed (g), and injected with PIT tags prior to stocking, and those with tags were measured and weighed again upon harvest. Wild trout $W_{r}$ was obtained from 20 Appalachian streams throughout western NC between 2010 and 2015. Wilcoxon rank-sum test results ( $W$ - and $P$ values) for comparisons between the $W_{r}$ of hatchery-reared fish (at stocking and harvest) and that of wild fish are reported.

\begin{tabular}{|c|c|c|c|c|c|c|}
\hline Source & Origin & $N$ & $W_{r}$ & SE & $W$ & $P$ \\
\hline \multicolumn{7}{|c|}{ Brook Trout } \\
\hline NTR (stocking) & Hatchery & 31 & 103 & 2.2 & 3,720 & $<0.001$ \\
\hline NTR (harvest) & Hatchery & 31 & 89 & 1.5 & 2,409 & 0.722 \\
\hline EPRR (stocking) & Hatchery & 23 & 110 & 2.5 & 3,214 & $<0.001$ \\
\hline EPRR (harvest) & Hatchery & 23 & 102 & 2.8 & 2,692 & $<0.001$ \\
\hline $20 \mathrm{NC}$ & Wild & 162 & 84 & 1.8 & & \\
\hline $\begin{array}{l}\text { Appalachian } \\
\text { streams }\end{array}$ & & & & & & \\
\hline \multicolumn{7}{|c|}{ Brown Trout } \\
\hline NTR (stocking) & Hatchery & 33 & 103 & 2.0 & 2,528 & $<0.001$ \\
\hline NTR (harvest) & Hatchery & 33 & 89 & 1.9 & 1,146 & 0.003 \\
\hline EPRR (stocking) & Hatchery & 8 & 110 & 8.3 & 707 & 0.001 \\
\hline EPRR (harvest) & Hatchery & 8 & 98 & 6.0 & 413 & 0.942 \\
\hline $20 \mathrm{NC}$ & Wild & 105 & 93 & 0.8 & & \\
\hline \multicolumn{7}{|c|}{ Rainbow Trout } \\
\hline NTR (stocking) & Hatchery & 48 & 101 & 1.2 & 11,310 & $<0.001$ \\
\hline NTR (harvest) & Hatchery & 48 & 84 & 1.0 & 6,277 & 0.822 \\
\hline EPRR (stocking) & Hatchery & 27 & 97 & 1.2 & 6,120 & $<0.001$ \\
\hline EPRR (harvest) & Hatchery & 27 & 86 & 1.2 & 4,159 & 0.188 \\
\hline $\begin{array}{l}20 \mathrm{NC} \\
\text { Appalachian } \\
\text { streams }\end{array}$ & Wild & 267 & 85 & 0.7 & & \\
\hline
\end{tabular}

have resulted from rapid emigration in both systems (Flowers et al. 2019).

Although emigration after stocking and high-flow events was a dominant influence on the reduced density of stocked trout in delayed-harvest reaches (Flowers et al. 2019), high acute fishing mortality after stocking may have also affected estimates of density observed in CC and EPRR. Both delayed-harvest reaches were located in areas of easy access by anglers (i.e., within municipal or state park boundaries and along roadways), and decreased density after stocking may have resulted from hooking mortality associated with high angler effort. For instance, an evaluation of angler use in delayed-harvest reaches revealed the highest angler effort in EPRR and that individual trout stocked into delayed-harvest reaches of EPRR and the Nantahala River were captured 2.4-2.8 times compared to 


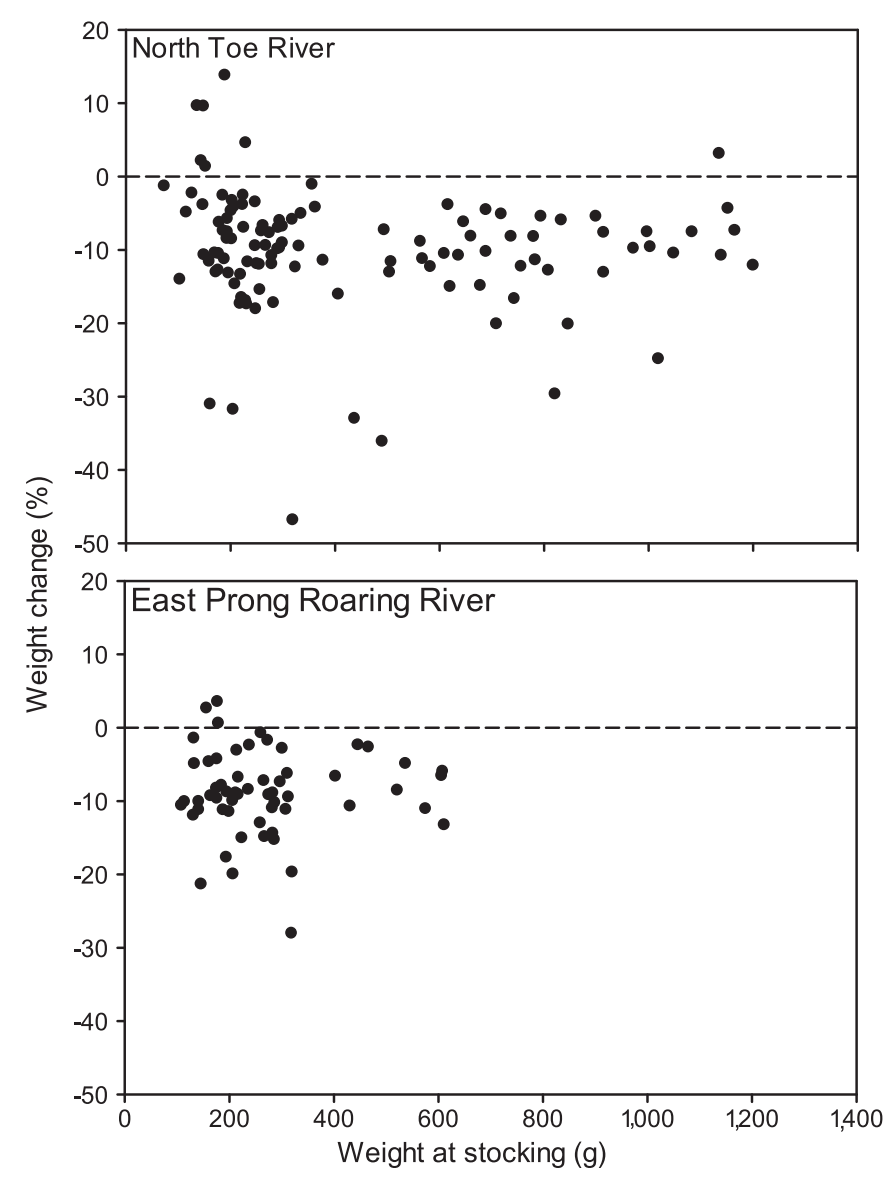

FIGURE 3. Percent change in body weight at harvest versus weight at stocking for hatchery-reared trout (Brook Trout, Brown Trout, and Rainbow Trout) stocked into the North Toe River in 2013 and the East Prong Roaring River in 2014. Fish weights were obtained from individually tagged fish that were harvested during the opening day of the harvest season from delayed-harvest reaches.

1.1-1.2 times each in hatchery-supported put-and-take reaches (Borawa et al. 1993, 2002). Finally, reduced density of hatchery-reared trout that occurred quickly after stocking may have partially resulted from illegal harvest, which was also observed in EPRR during the course of the study.

Natural mortality of recently stocked fish may have also resulted from predators, such as mammals, snakes, and birds, which were all directly observed by us as sources of mortality immediately after stocking, when trout densities were highest. Avian piscivores specifically have been documented to reduce production at hatchery facilities (Schramm et al. 1987; Parkhurst et al. 1992; Pitt and Conover 1996), and predation on stocked trout by both avian and mammalian predators can be substantial after stocking (Derby and Lovvorn 1997; Jacobsen 2005). Although we did not quantify predation mortality in our study, our observations support previously published

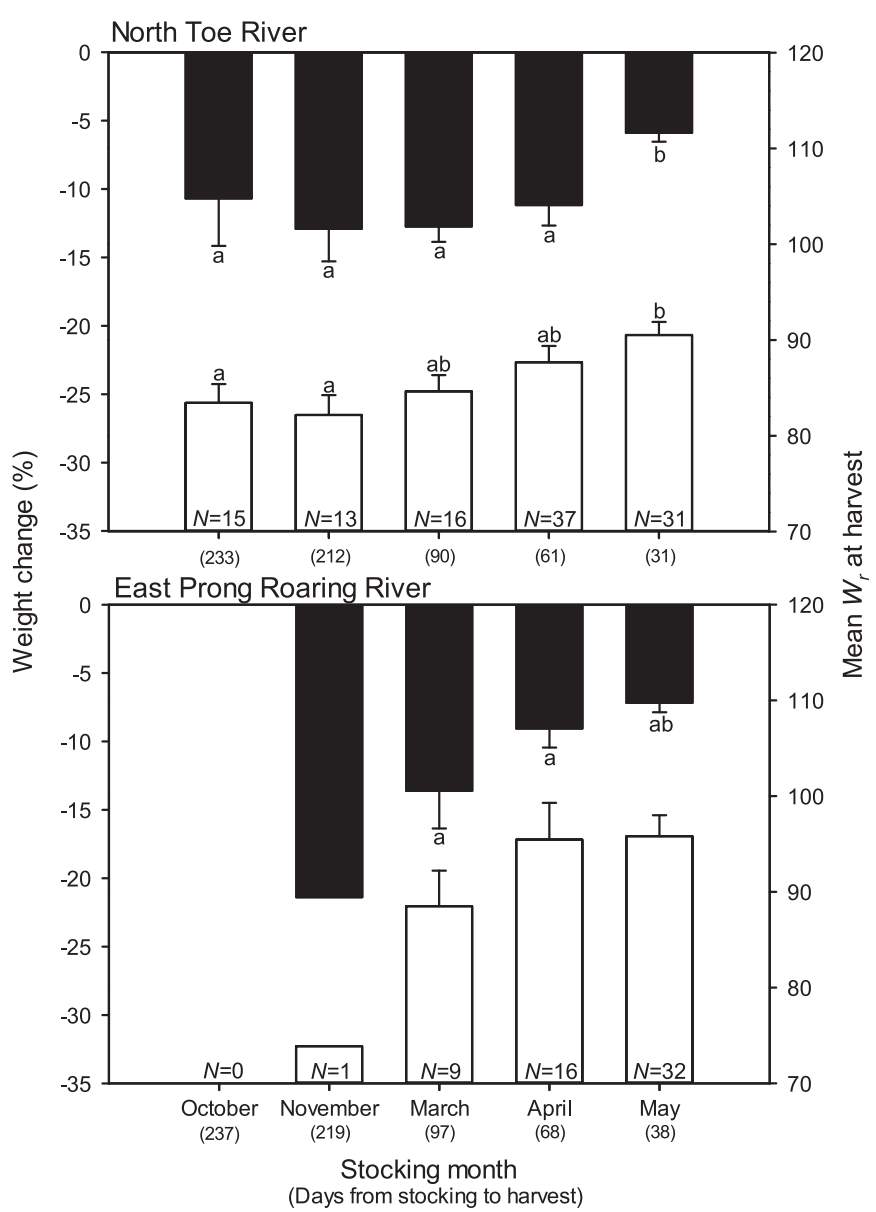

FIGURE 4. Mean (+SE) percent change in body weight at harvest (solid bars) and mean relative weight ( $W_{r}$; open bars) by stocking month for hatchery-reared trout (Brook Trout, Brown Trout, and Rainbow Trout) stocked into the North Toe River in 2013 and the East Prong Roaring River in 2014. Fish weights were obtained from PIT-tagged fish that were harvested during the opening day of the harvest season from delayed-harvest reaches. Different letters indicate significant differences based on the results of Dunn's tests for multiple comparisons using a Bonferroni adjustment.

findings that high densities of stocked trout are vulnerable to predation, particularly in small, clear mountain streams.

\section{Temporal Characteristics of Hatchery-Reared Trout Condition and Growth}

Recaptured hatchery-reared trout typically lose weight immediately after stocking, but those that survive usually begin to grow after several months (Needham and Slater 1945; Miller 1952; Baer and Brinker 2008a, 2008b). The observed inverse association between stream residence time and $W_{r}$ of stocked trout in CC and EPRR suggested that trout did not begin to grow in delayed-harvest reaches, whereas the positive relationship between condition and density of stocked trout is likely an artifact of 

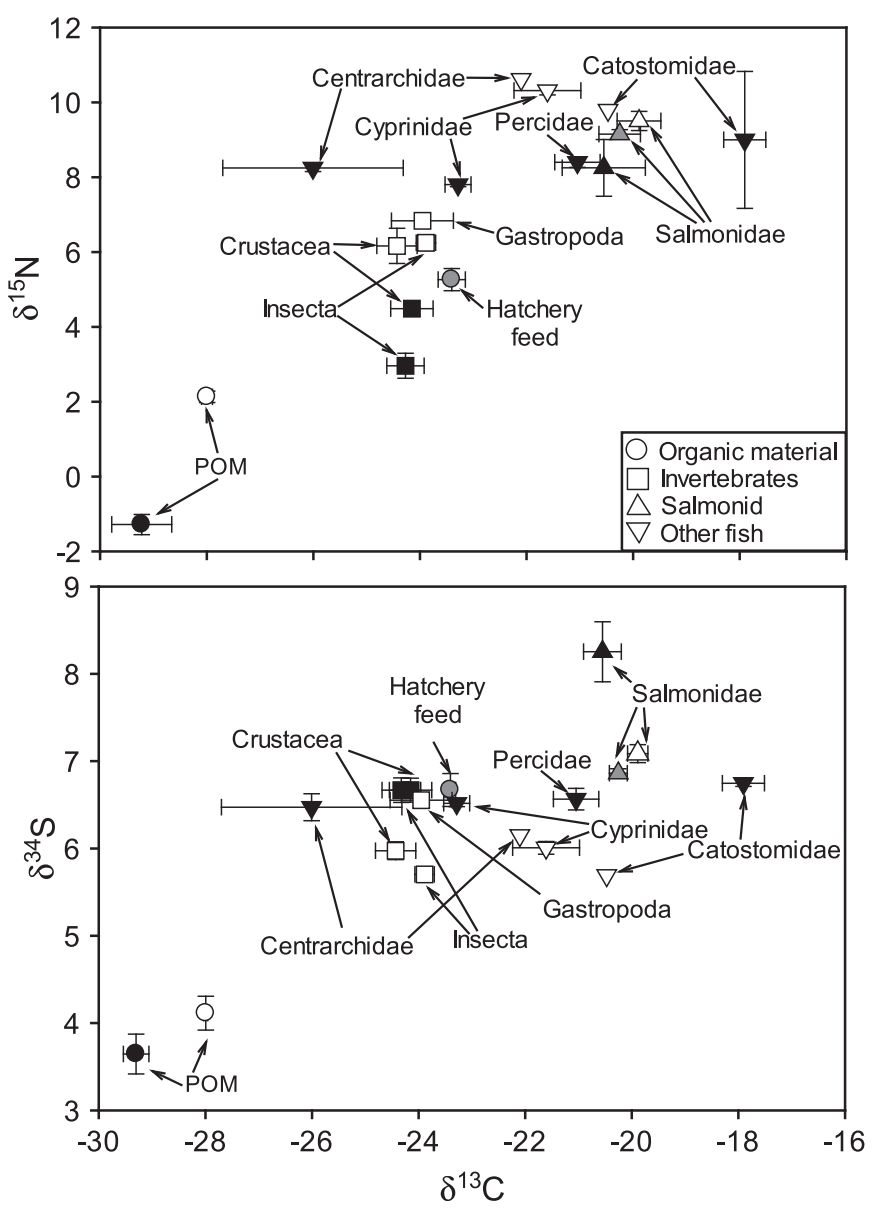

FIGURE 5. Biplots of mean $( \pm \mathrm{SE}) \delta^{15} \mathrm{~N}, \delta^{34} \mathrm{~S}$, and $\delta^{13} \mathrm{C}$ isotope ratios $(\%)$ for hatchery feed, stream particulate organic matter (POM), invertebrates, and fish from hatcheries, Cane Creek (CC), and the East Prong Roaring River (EPRR) in western North Carolina. Trout from CC and EPRR represent both wild and stocked fish. Sample origin is represented by symbol fill $($ open $=\mathrm{CC}$; black $=\mathrm{EPRR}$; gray $=$ hatchery).

sample timing rather than an ecological density-dependent effect. Specifically, densities of hatchery-reared trout were highest after stocking, when the $W_{r}$ values of recently stocked fish were also high. Despite the declines in body condition of hatchery-reared trout, the values of $W_{r}$ for fish stocked into delayed-harvest reaches were generally greater than the values observed for self-sustaining, wild trout populations in the region. The maintenance of relatively high $W_{r}$ was also consistent with the temporal patterns of $W_{r}$ observed for fish harvested in NTR and EPRR. Individually tagged trout harvested from NTR and EPRR consistently lost weight after stocking, and absolute growth was not correlated with size at stocking. Additionally, we did not observe an increase in growth for fish with the greatest residence time, although such an increase has been reported for Brown Trout in other systems (e.g., Baer and Brinker 2008a, 2008b). Overall, weight loss among all trout species suggests that (1) food resources may not have been available in quantities required to maintain trout biomass at the densities stocked or (2) stocked individuals did not learn to feed on the natural prey items that were available. However, our diet examination of trout sampled from CC and EPRR documented the presence of aquatic invertebrates in the stomachs of stocked and harvested trout with residence times in excess of $200 \mathrm{~d}$, which indicated that some of the surviving hatchery-reared fish were actively feeding.

\section{Diet and Isotopic Composition of Hatchery-Reared and Wild Trout}

Drifting invertebrates are the primary prey consumed by trout in southern Appalachian Mountain streams (Cada et al. 1987; Romaniszyn et al. 2007), but benthic feeding by lotic salmonids has also been well documented (Bachman 1984; McIntosh and Townsend 1995) and can be greatest during the night (Elliott 1973; Angradi and Griffith 1990) or at reduced water temperatures, where nocturnal feeding may become predominant (Cunjak 1988; Fraser et al. 1993). Even with limited sample sizes for wild fish (26 fish total), we observed clear differences in diets between trout of hatchery and wild origin, suggesting that fish and benthic prey (i.e., gastropods and crustaceans) are important food resources during winter, when aquatic invertebrate drift and terrestrial inputs may be rare (Cunjak and Power 1987; Newman 1987). Our finding of an increased frequency of snails and crayfish in the wild trout diet is similar to the findings of Bisson (1987), who documented increased relative frequency of gastropods in the diets of Rainbow Trout collected at night. Additionally, Bisson (1987) observed that larger trout were more likely to feed on benthic prey resources than smaller trout.

The SIA of organic matter from CC and EPRR indicated similar patterns of trophic structuring between rivers. However, ${ }^{15} \mathrm{~N}$ enrichment of $\mathrm{POM}$ and primary consumers in $\mathrm{CC}$ from potential anthropogenic sources may have resulted from the proximity of the delayed-harvest reach within the town of Bakersville, North Carolina, compared to that of EPRR within the largely wooded Stone Mountain State Park. Our SIA indicated that based on trophic positions, all three trout species were among the apex predators in both systems. Isotopic differentiation was not detected for trout obtained directly from the Armstrong State Fish Hatchery relative to trout collected from CC and EPRR; this was likely due to the hatchery feed being within the range of carbon, nitrogen, and sulfur stable isotopic signatures for potential instream prey items (i.e., insects, crustaceans, and nontrout fishes). This relation might have differed if another type and source of hatchery trout feed (e.g., that included marine fish meal) had been used. However, 
TABLE 2. Stable isotope ratios $(\%)$ of hatchery and wild trout muscle tissue samples from Cane Creek (CC) and the East Prong Roaring River (EPRR) in western North Carolina, 2012-2013. Data are sample size $(N)$ and mean $\delta$ values $( \pm \mathrm{SE})$ for each element $(\mathrm{NA}=$ no fish were collected).

\begin{tabular}{|c|c|c|c|c|c|}
\hline Source & Origin & $N$ & $\delta^{13} \mathrm{C}$ & $\delta^{15} \mathrm{~N}$ & $\delta^{34} \mathrm{~S}$ \\
\hline \multicolumn{6}{|c|}{ Brook Trout } \\
\hline $\mathrm{CC}$ & Hatchery & 24 & $-20.2 \pm 0.05$ & $8.9 \pm 0.04$ & $6.9 \pm 0.06$ \\
\hline $\mathrm{CC}$ & Wild & 3 & $-19.2 \pm 0.10$ & $9.2 \pm 0.01$ & $7.3 \pm 0.10$ \\
\hline EPRR & Hatchery & 14 & $-20.3 \pm 0.07$ & $8.9 \pm 0.07$ & $6.9 \pm 0.10$ \\
\hline EPRR & Wild & NA & NA & NA & NA \\
\hline \multicolumn{6}{|c|}{ Brown Trout } \\
\hline $\mathrm{CC}$ & Hatchery & 23 & $-20.2 \pm 0.08$ & $9.3 \pm 0.14$ & $6.7 \pm 0.10$ \\
\hline $\mathrm{CC}$ & Wild & 9 & $-20.1 \pm 0.26$ & $9.8 \pm 0.07$ & $7.0 \pm 0.14$ \\
\hline EPRR & Hatchery & 20 & $-20.2 \pm 0.06$ & $9.1 \pm 0.08$ & $7.0 \pm 0.11$ \\
\hline EPRR & Wild & 7 & $-21.0 \pm 0.56$ & $7.7 \pm 0.49$ & $7.5 \pm 0.09$ \\
\hline \multicolumn{6}{|c|}{ Rainbow Trout } \\
\hline $\mathrm{CC}$ & Hatchery & 35 & $-20.2 \pm 0.04$ & $9.0 \pm 0.05$ & $6.7 \pm 0.06$ \\
\hline $\mathrm{CC}$ & Wild & 2 & $-19.9 \pm 0.07$ & $8.8 \pm 0.25$ & $7.4 \pm 0.01$ \\
\hline EPRR & Hatchery & 26 & $-20.2 \pm 0.06$ & $9.1 \pm 0.06$ & $6.8 \pm 0.06$ \\
\hline EPRR & Wild & 5 & $-20.0 \pm 0.07$ & $9.0 \pm 0.14$ & $7.4 \pm 0.01$ \\
\hline
\end{tabular}

further inspection into trout isotopic composition indicated greater variability in mean $\delta^{13} \mathrm{C}, \delta^{15} \mathrm{~N}$, and $\delta^{34} \mathrm{~S}$ measured for wild trout relative to hatchery-reared individuals for a majority of isotopes in all three trout species. Increased variation in stable isotope signatures suggests increased diet breadth among wild trout, in accordance with the concurrent diet analysis. Additionally, we found no evidence that the isotopic composition of hatchery trout tissue became similar to that of wild trout over time, which suggests minimal incorporation of natural foods into the muscle of stocked fish. Additionally, only mean $\delta^{34} \mathrm{~S}$ of wild trout tissue was consistently higher than that of hatchery-reared trout for all three species. Estimates of isotopic turnover and half-life from muscle tissue samples of ectotherms are highly variable (McIntyre and Flecker 2006; Weidel et al. 2011), are dependent on body mass, and are similar among ${ }^{13} \mathrm{C}$, ${ }^{15} \mathrm{~N}$, and ${ }^{34} \mathrm{~S}$ (Vander Zanden et al. 2015). Applying the approach presented by Vander Zanden et al. (2015; $\log _{e}[-$ half-life $]=0.22 \cdot \log _{e}[$ body mass $\left.]+3.28\right)$, the estimated half-life for an average hatchery-reared trout (mean weight $=165 \mathrm{~g}$ ) in our research was $82 \mathrm{~d}$. As such, isotopic turnover should have been observed for hatcheryreared trout with instream residence times of up to $200 \mathrm{~d}$. Stability in isotopic composition and minimal variation over time suggest limited incorporation of natural prey resources into the body mass of stocked trout and were consistent with the negative growth we observed in recaptured and harvested individuals.

\section{Conclusions and Implications}

Our study of the trophic relations of hatchery-reared trout stocked into delayed-harvest reaches of southern
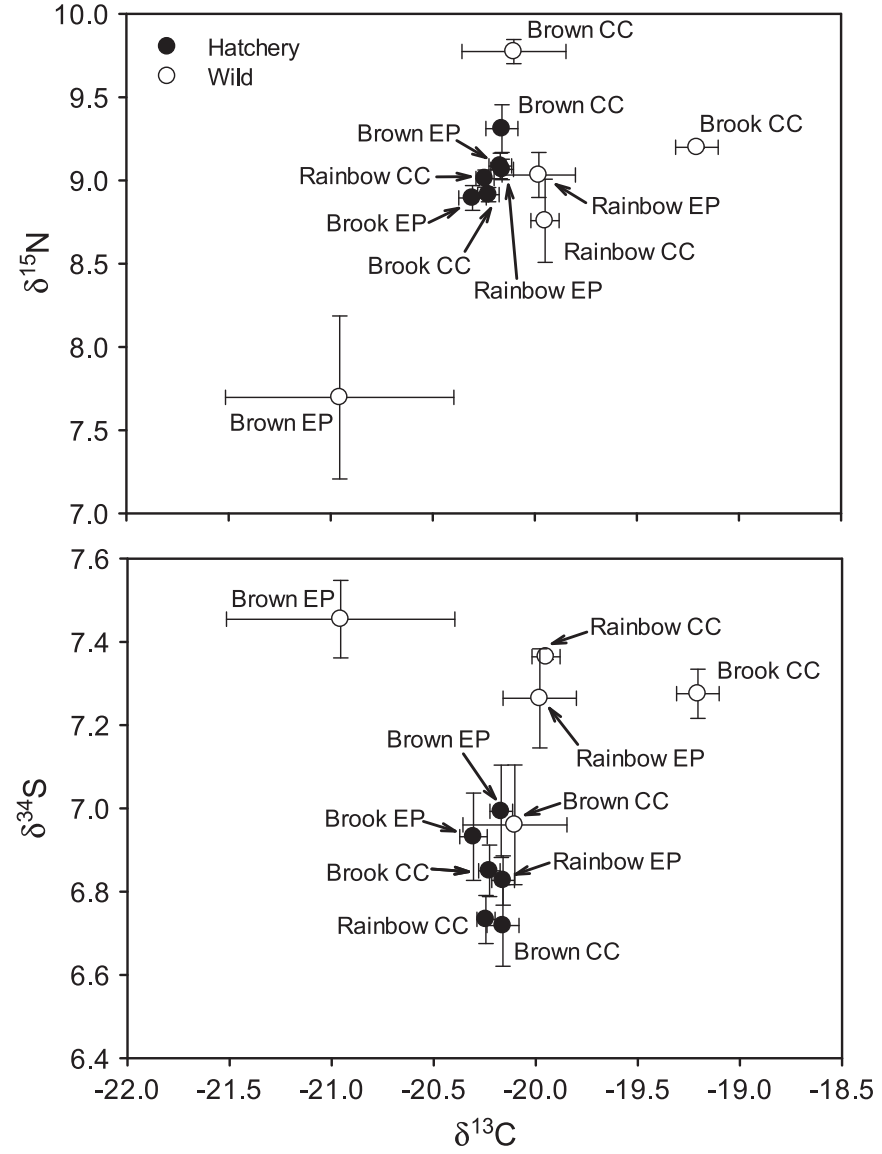

FIGURE 6. Biplots of mean $( \pm \mathrm{SE}) \delta^{15} \mathrm{~N}, \delta^{34} \mathrm{~S}$, and $\delta^{13} \mathrm{C}$ isotope ratios $(\%)$ from hatchery-reared (solid symbols) and wild (open symbols) Brook Trout (Brook), Brown Trout (Brown), and Rainbow Trout (Rainbow) from Cane Creek (CC) and the East Prong Roaring River (EP) in western North Carolina. 

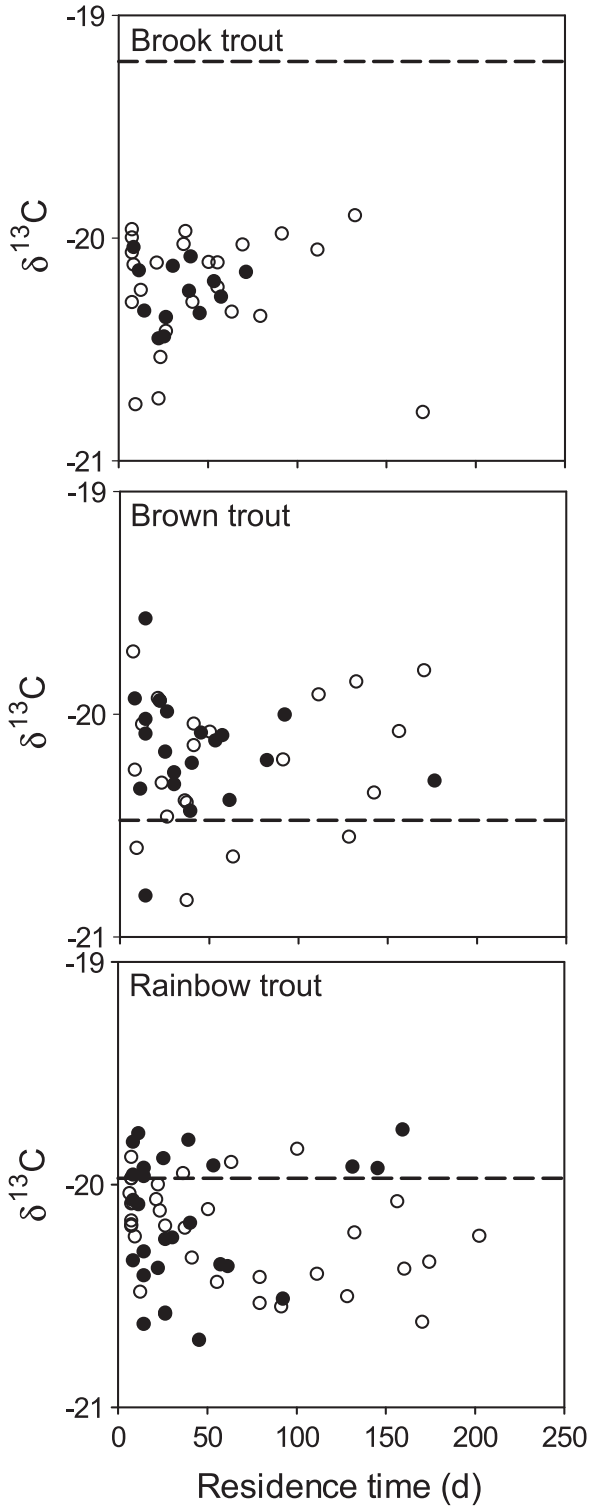
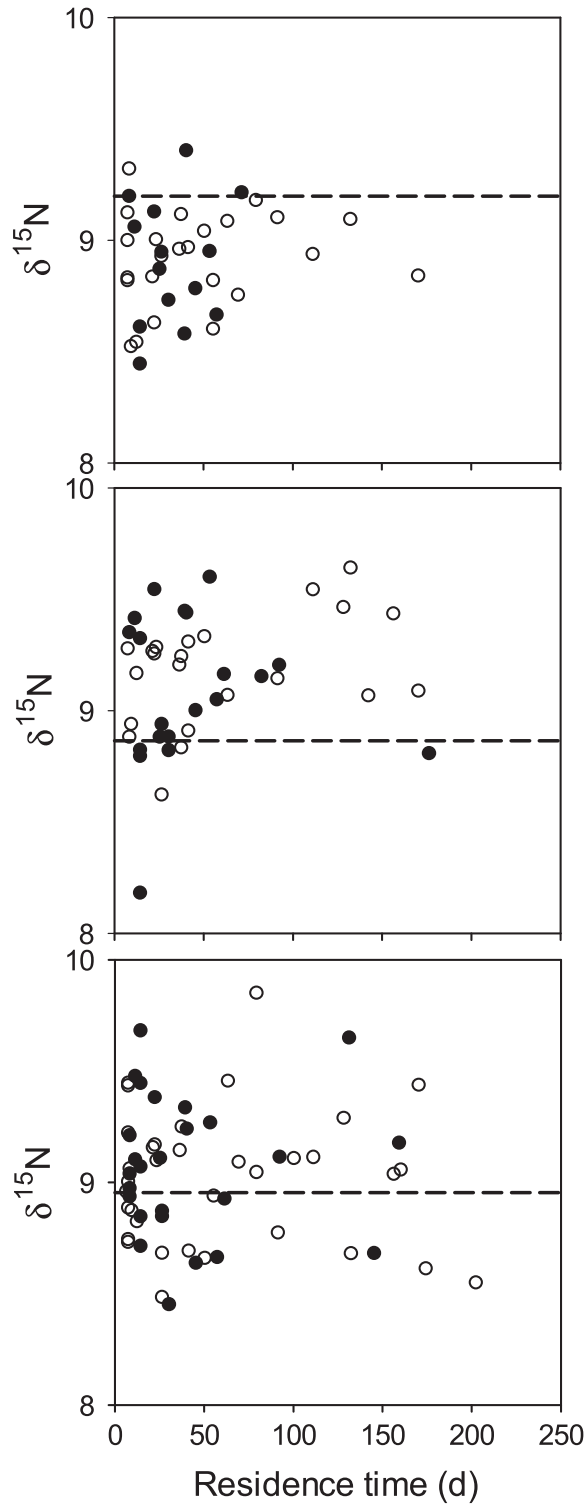
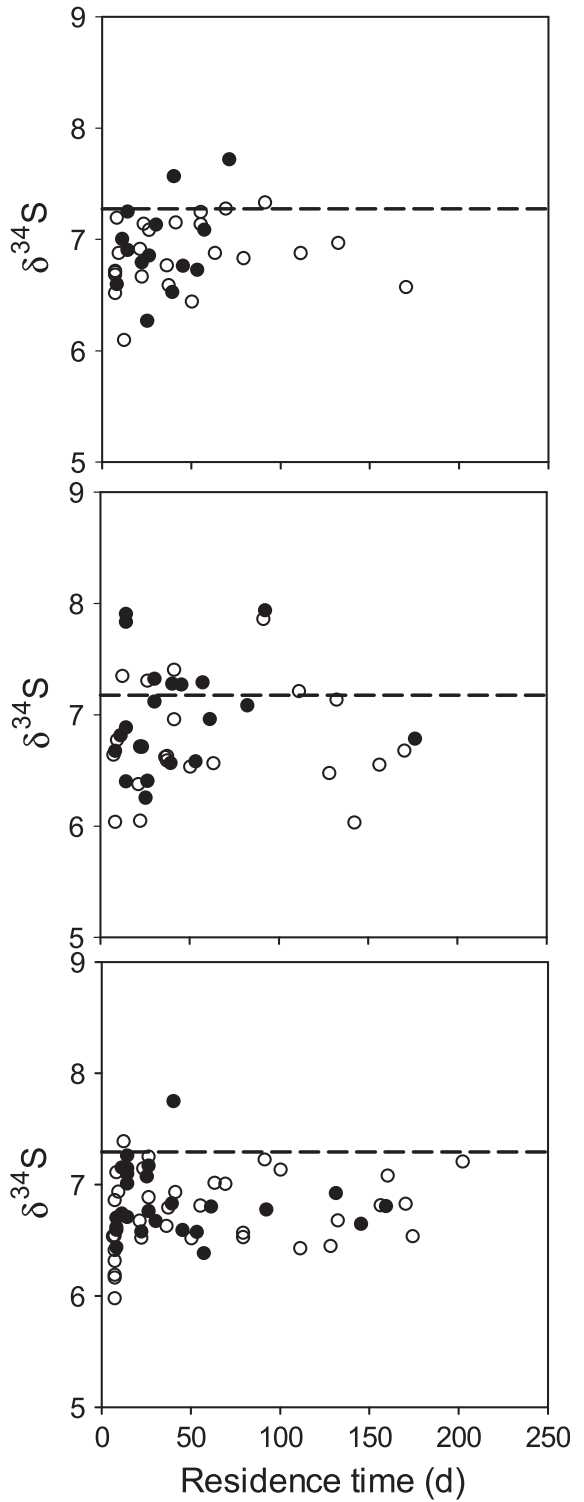

FIGURE 7. Stable isotope ratios $\left(\delta^{15} \mathrm{~N}, \delta^{34} \mathrm{~S}\right.$, and $\delta^{13} \mathrm{C} ; \%$ ) versus instream residence time (d since stocking) for hatchery-reared Brook Trout, Brown Trout, and Rainbow Trout sampled from Cane Creek (open circles) and the East Prong Roaring River (solid circles) in western North Carolina. Horizontal dashed lines indicate the mean isotope ratio values from wild fish.

Appalachian Mountain streams has several implications for the evaluation and refinement of stocking programs. First, our temporal characterization of density and contribution of previously stocked trout over time indicated that persistence of fall-stocked trout in delayed-harvest reaches was lower than that of trout stocked in the spring, and fall-stocked trout contributed $2-25 \%$ of harvested trout during the season opening day. Increased fishing opportunities and multiple catches throughout the fall and winter may justify the low proportions of creel returns of fallstocked fish. Conversely, repeated stocking of trout in the spring resulted in more evenly distributed contributions to creel returns and provided catch-and-release angling opportunities before allowable harvest. Although hatchery-reared trout consistently lost weight as residence time increased, the individual body mass attained in the hatchery prior to stocking allowed those fish to retain a level of body condition similar to or higher than that of wild populations at harvest. Our findings of decreased feeding and the lack of isotopic incorporation may be particularly useful in guiding hatchery and stocking procedures. For instance, enhancing instream structure in hatcheries (Brockmark et al. 2007), rearing fish in ponds rather than raceways (Zydlewski et al. 2003), and decreasing densities 
FISCHER ET AL.

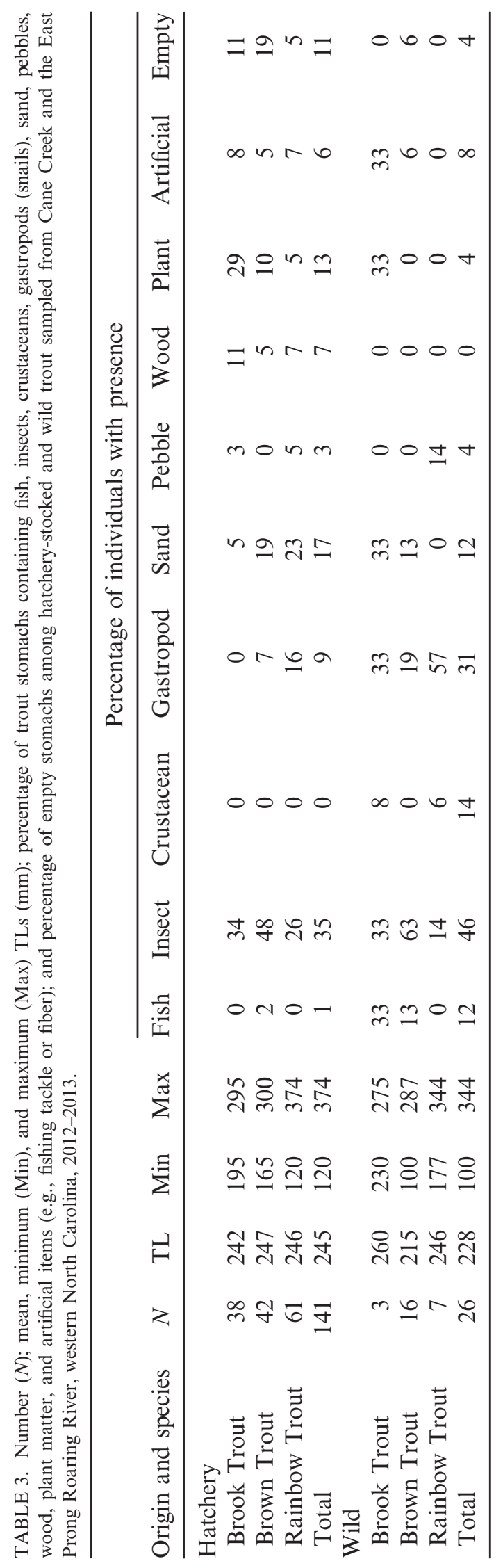


in hatcheries (Kavanagh and Olsen 2014) can improve the physical condition, growth, and survival of hatcheryreared salmonids. However, the benefits of such actions must outweigh the costs of production and warrant further research in hatchery-supported southern Appalachian Mountain trout streams. Overall, these combined results provide critical insight on the life history and trophic relations of hatchery-reared trout and serve to adjust expectations and outcomes from stocking efforts used to enhance quality trout fisheries in southern Appalachian Mountain streams.

\section{ACKNOWLEDGMENTS}

We thank Kyle Briggs, David Deaton, Spike Gouge, Kevin Hining, Peter Lamb, Jimmy Lowman, and Matt Rimmer (NCWRC) for their technical assistance and support. Patrick Cooney, Thomas Johnson, Byron Levan, Michael Walter, and James Wehbie assisted with field work. Janet Pearson (North Carolina Division of Parks and Recreation) provided logistic support during sampling and research staff housing at Stone Mountain State Park. This research was funded with Sport Fish Restoration Funds through the NCWRC (Project F-98-R). The North Carolina Cooperative Fish and Wildlife Research Unit is jointly supported by North Carolina State University, NCWRC, U.S. Geological Survey, U.S. Fish and Wildlife Service, and Wildlife Management Institute. Any use of trade, firm, or product names is for descriptive purposes only and does not imply endorsement by the U.S. Government. There is no conflict of interest declared in this article.

\section{ORCID}

Thomas J. Kwak (D) https://orcid.org/0000-0002-0616$137 \mathrm{X}$

W. Gregory Cope (D) https://orcid.org/0000-0003-27451939

\section{REFERENCES}

Agresti, A. 2007. An introduction to categorical data analysis, 2nd edition. Wiley, New York.

Angradi, T. R., and J. S. Griffith. 1990. Diel feeding chronology and diet selection of Rainbow Trout (Oncorhynchus mykiss) in the Henry's Fork of the Snake River, Idaho. Canadian Journal of Fisheries and Aquatic Sciences 47:199-209.

Bachman, R. A. 1984. Foraging behavior of free-ranging wild and hatchery Brown Trout in a stream. Transactions of the American Fisheries Society 113:1-32.

Baer, J., and A. Brinker. 2008a. Pre-stocking acclimatisation of Brown Trout Salmo trutta: effects on growth and capture in a fast-flowing river. Fisheries Management and Ecology 15:119-126.

Baer, J., and A. Brinker. 2008b. Are growth and recapture of hatcheryreared and resident Brown Trout (Salmo trutta L.) density dependent after stocking? Ecology of Freshwater Fish 15:119-126.
Bateman, D. S., and R. E. Gresswell. 2006. Survival and growth of age-0 steelhead after surgical implantation of $23-\mathrm{mm}$ passive integrated transponders. North American Journal of Fisheries Management 26:545-550.

Bettinger, J. M., and P. W. Bettoli. 2002. Fate, dispersal, and persistence of recently stocked and resident Rainbow Trout in a Tennessee tailwater. North American Journal of Fisheries Management 22:425432.

Bisson, P. A. 1987. Diel food selection by two sizes of Rainbow Trout (Salmo gairdneri) in an experimental stream. Journal of the Fisheries Research Board of Canada 35:971-975.

Borawa, J. C., J. H. Mickey Jr., and M. S. Davis. 1993. First year assessment of delayed harvest trout regulations. Proceedings of the Annual Conference Southeastern Association of Fish and Wildlife Agencies 47:642-649.

Borawa, J. C., J. H. Mickey Jr., C. J. Goudreau, and M. M. Clemmons. 2002. Evaluation of an extended delayed harvest trout season on five North Carolina trout streams. North Carolina Wildlife Resources Commission, Division of Inland Fisheries, Raleigh.

Bowen, S. H. 1996. Quantitative description of the diet. Pages 513-532 in B. R. Murphy and D. W. Willis, editors. Fisheries techniques, 2nd edition. American Fisheries Society, Bethesda, Maryland.

Brockmark, S., L. Neregård, T. Bohlin, B. T. Björnsson, and J. I. Johnsson. 2007. Effects of rearing density and structural complexity on the pre- and postrelease performance of Atlantic Salmon. Transactions of the American Fisheries Society 136:1453-1462.

Cada, G. F., J. M. Loar, and D. K. Cox. 1987. Food and feeding preferences of Rainbow and Brown trout in southern Appalachian streams. American Midland Naturalist 117:374-385.

Cresswell, R. C. 1981. Post-stocking movements and recapture of hatchery-reared trout released into flowing waters-a review. Journal of Fish Biology 18:429-442.

Cunjak, R. A. 1988. Behaviour and microhabitat of young Atlantic Salmon (Salmo salar) during winter. Canadian Journal of Fisheries and Aquatic Sciences 45:2156-2160.

Cunjak, R. A., and G. Power. 1987. The feeding and energetics of stream-resident trout in winter. Journal of Fish Biology 31:493-511.

Derby, C. E., and J. R. Lovvorn. 1997. Predation on fish by cormorants and pelicans in a cold-water river: a field and modeling study. Canadian Journal of Fisheries and Aquatic Sciences 54:1480-1493.

Dunn, O. J. 1961. Multiple comparisons among means. Journal of the American Statistical Association 56:52-64.

Einum, S., and I. A. Fleming. 2001. Implications of stocking: ecological interactions between wild and released salmonids. Nordic Journal of Freshwater Research 75:56-70.

Elliott, J. M. 1973. The food of Brown and Rainbow trout (Salmo trutta and $S$. gairdneri) in relation to the abundance of drifting invertebrates in a mountain stream. Oecologia 12:329-347.

Flowers, H. J., T. J. Kwak, J. R. Fischer, W. G. Cope, J. M. Rash, and D. A. Besler. 2019. Behavior and survival of stocked trout in southern Appalachian Mountain streams. Transactions of the American Fisheries Society 148:3-20.

Fraser, N. H. C., N. B. Metcalfe, and J. E. Thorpe. 1993. Temperaturedependent switch between diurnal and nocturnal foraging in salmon. Proceedings of the Royal Society of London Series B: Biological Sciences 252:135-139.

Fry, B. 1991. Stable isotope diagrams of freshwater food webs. Ecology 72:2293-2297.

Halverson, M. A. 2008. Stocking trends: a quantitative review of governmental fish stocking in the United States, 1931 to 2004. Fisheries 33:69-75.

Hartman, K., J. Howell, and K. Semmens. 2012. Habitat use, survival, and site fidelity of Rainbow Trout stocked into an Appalachian river. Journal of Applied Aquaculture 24:299-315. 
Hayes, D. B., J. R. Bence, T. J. Kwak, and B. E. Thompson. 2007. Abundance, biomass, and production estimation. Pages 327-374 in C. S. Guy and M. L. Brown, editors. Analysis and interpretation of freshwater fisheries data. American Fisheries Society, Bethesda, Maryland.

Heidinger, R. C. 1999. Stocking for sport fisheries enhancement. Pages 375-401 in C. C. Kohler and W. A. Hubert, editors. Inland fisheries management in North America, 2nd edition. American Fisheries Society, Bethesda, Maryland.

Jacobsen, L. 2005. Otter (Lutra lutra) predation on stocked Brown Trout (Salmo trutta) in two Danish lowland rivers. Ecology of Freshwater Fish 14:59-68.

Kavanagh, M., and D. E. Olsen. 2014. The effects of rearing density on growth, fin erosion, survival, and migration behavior of hatchery winter steelhead. North American Journal of Aquaculture 76:323-332.

Kwak, T. J., and J. B. Zedler. 1997. Food web analysis of southern California coastal wetlands using multiple stable isotopes. Oecologia 110:262-277.

McIntosh, A. R., and C. R. Townsend. 1995. Contrasting predation risks presented by introduced Brown Trout and native Common River Galaxias in New Zealand streams. Canadian Journal of Fisheries and Aquatic Sciences 52:1821-1833.

McIntyre, P. B., and A. S. Flecker. 2006. Rapid turnover of tissue nitrogen of primary consumers in tropical freshwaters. Oecologia 148:1221

Miller, R. B. 1952. Survival of hatchery-reared Cutthroat Trout in an Alberta stream. Transactions of the American Fisheries Society 81:35-42.

Miller, R. B. 1953. Comparative survival of wild and hatchery-reared Cutthroat Trout in a stream. Transactions of the American Fisheries Society $83: 120-130$

Needham, P. R. 1959. New horizons in stocking hatchery trout. Transactions of the North American Wildlife Conference 24:395-407.

Needham, P. R., and D. W. Slater. 1944. Survival of hatchery-reared Brown and Rainbow trout as affected by wild trout populations. Journal of Wildlife Management 7:18-23.

Needham, P. R., and D. W. Slater. 1945. Seasonal changes in growth, mortality, and condition of Rainbow Trout following planting. Transactions of the American Fisheries Society 73:117-124.

Neumann, R. M., C. S. Guy, and D. W. Willis. 2012. Length, weight, and associated indices. Pages 637-676 in A. V. Murphy, D. L. Parrish, and T. M. Sutton, editors. Fisheries techniques, 3rd edition. American Fisheries Society, Bethesda, Maryland.

Newman, R. M. 1987. Comparison of encounter model predictions with observed size-selectivity by stream trout. Journal of the North American Benthological Society 6:56-64.

Ogle, D. H. 2018. FSA: Fisheries Stock Analysis. R package version 0.8.20. Available: https://cran.r-project.org/package=FSA. (May 2019).

Parkhurst, J. A., R. P. Brooks, and D. E. Arnold. 1992. Assessment of predation at trout hatcheries in central Pennsylvania. Wildlife Society Bulletin 20:411-419.

Peterson, B. J., and B. Fry. 1987. Stable isotopes in ecosystem studies. Annual Review of Ecology and Systematics 18:293-320.

Pitt, W. C., and M. R. Conover. 1996. Predation at Intermountain West fish hatcheries. Journal of Wildlife Management 60:616-624.

Polis, G. A., and K. O. Winemiller, editors. 1996. Food webs: integration of patterns and dynamics. Chapman and Hall, London.
R Core Team. 2018. R: a language and environment for statistical computing. R Foundation for Statistical Computing, Vienna. Available: https://www.R-project.org/. (May 2019).

Romaniszyn, E. D., J. J. Hutchens Jr., and J. B. Wallace. 2007. Aquatic and terrestrial invertebrate drift in southern Appalachian Mountain streams: implications for trout food resources. Freshwater Biology 52:1-11.

Schramm, H. L. Jr., E. A. Okrah, and M. W. Collopy. 1987. Potential problems of bird predation for fish culture in Florida. Progressive Fish-Culturist 49:44-49.

Seber, G. A. F. 1982. The estimation of animal abundance and related parameters, 2nd edition. Oxford University Press, New York.

Teixeira, A., and R. M. V. Cortes. 2006. Diet of stocked and wild trout, Salmo trutta: is there competition for resources? Folia Zoologica 55:61-73.

Trushenski, J., T. Flagg, and C. Kohler. 2010. Use of hatchery fish for conservation, restoration, and enhancement of fisheries. Pages 261293 in W. A. Hubert and M. C. Quist, editors. Inland fisheries management in North America, 3rd edition. American Fisheries Society, Bethesda, Maryland.

Turek, K. C., M. A. Pegg, K. L. Pope, and S. Schainost. 2014. Potential population and assemblage influences of non-native trout on native nongame fish in Nebraska headwater streams. Ecology of Freshwater Fish 25:99-108.

USFWS (U.S. Fish and Wildlife Service) and USCB (U.S. Census Bureau). 2011. 2011 national survey of fishing, hunting, and wildlifeassociated recreation. USFWS and USCB, Washington, D.C.

Vander Zanden, M. J., M. K. Clayton, E. K. Moody, C. T. Solomon, and B. C. Weidel. 2015. Stable isotope turnover and half-life in animal tissues: a literature synthesis. PLoS ONE [online serial] 10(1): e0116182.

Walters, J. P., T. D. Fresques, and S. D. Bryan. 1997. Comparison of creel returns from Rainbow Trout stocked at two sizes. North American Journal of Fisheries Management 17:474-476.

Weaver, D. M., and T. J. Kwak. 2013. Assessing effects of stocked trout on nongame fish assemblages in southern Appalachian Mountain streams. Transactions of the American Fisheries Society 142:1495-1507.

Weber, E. D., and K. D. Fausch. 2003. Interactions between hatchery and wild salmonids in streams: differences in biology and evidence for competition. Canadian Journal of Fisheries and Aquatic Sciences 60:1018-1036.

Weidel, B. C., S. R. Carpenter, J. F. Kitchell, and M. J. Vander Zanden. 2011. Rates and components of carbon turnover in fish muscle: insights from bioenergetics models and a whole-lake ${ }^{13} \mathrm{C}$ addition. Canadian Journal of Fisheries and Aquatic Sciences 68:387-399.

Wiley, R. W., R. A. Whaley, J. B. Satake, and M. Fowden. 1993a. Assessment of stocking hatchery trout: a Wyoming perspective. North American Journal of Fisheries Management 13:160-170.

Wiley, R. W., R. A. Whaley, J. B. Satake, and M. Fowden. 1993b. An evaluation of the potential for training trout in hatcheries to increase poststocking survival in streams. North American Journal of Fisheries Management 13:171-177.

Zar, J. H. 1999. Biostatistical analysis, 4th edition. Prentice Hall, Englewood Cliffs, New Jersey.

Zydlewski, G. B., J. S. Foott, K. Nichols, S. Hamelberg, J. Zydlewski, and B. T. Björnsson. 2003. Enhanced smolt characteristics of steelhead trout exposed to alternative hatchery conditions during the final month of rearing. Aquaculture 222:101-117. 